\title{
Collaboration Enables Innovative Timber Structure Adoption in Construction
}

\author{
Annie Gosselin ${ }^{1, *}$, Pierre Blanchet $\left.{ }^{2}{ }^{(}\right)$, Nadia Lehoux ${ }^{3}$ and Yan Cimon ${ }^{4}$ \\ 1 Timber Building Industry Development Adviser at Ministry of Forest, Fauna and Parks, Direction of Timber \\ Products Industry Development, 5700, 4e Avenue Ouest, A 409, Quebec, QC G1H 6R1, Canada \\ 2 NSERC Industrial Chair on Ecoresponsible Wood Construction-CIRCERB, Laval University, \\ Gene-H.-Kruger Building, 2425, Rue de la Terrasse, Quebec, QC G1V 0A6, Canada; \\ pierre.blanchet@sbf.ulaval.ca \\ 3 Department of Mechanical Engineering, Engineering and Sciences Faculty, Laval University, Adrien-Pouliot \\ Building, 1065, av. de la Médecine, Bureau 1504, Quebec, QC G1V 0A6, Canada; \\ Nadia.Lehoux@gmc.ulaval.ca \\ 4 Interuniversity Research Center on Enterprise Networks, Logistics and Transportation-CIRRELT, \\ Department of management, Administration Sciences Faculty, Laval University, Palasis-Prince Building, \\ 2325, Rue de la Terrasse, Quebec, QC G1V 0A6, Canada; Yan.Cimon@fsa.ulaval.ca \\ * Correspondence: annie.gosselin.1@ulaval.ca; Tel.: +1-418-905-3743
}

Received: 9 October 2018; Accepted: 12 December 2018; Published: 19 December 2018

check for updates

\begin{abstract}
Timber structures in construction have become more popular in recent years. Nevertheless, besides the complexity of designing, contracting and building these structures, a barrier to their market growth is the complexity of their supply chain relationships encompassing architects, engineers, builders and suppliers. The objective of this study is therefore to identify and characterize the supply chain relationships shared by these stakeholders within a massive timber construction project. Twenty-seven semi-structured interviews with architects, structural engineers, builders and timber element suppliers from nine countries, participant observations and secondary data were used to study the various relationship levels involved in timber construction projects. Triangulation and qualitative data analysis were also conducted. Three levels of relationships were then identified: "Contractual," "Massive timber construction project" and "Massive timber construction industry development." Results showed that timber structures involve value-added stakeholder relationships rather than linear relationships. These relationships appeared closer and more frequent and involved knowledge and information sharing. Furthermore, prefabricated systems allow for smoother relationships by limiting the number of stakeholders while promoting innovative thinking.
\end{abstract}

Keywords: collaboration; construction; supply chain; innovation; interviews

\section{Introduction}

Ever since the industrial revolution, concrete and steel have been the dominant building materials used for most kinds of buildings. Except for the residential sector where timber structures are predominant in many countries such as Canada, USA, Scandinavia and UK, most institutional, commercial, industrial and residential multi-story buildings are erected on structures made from concrete and steel. Since the 1960s, engineered wood products, which can be defined as manufactured products optimizing wood fibres, have been entering the structural material market. Manufacturing methods were developed to eliminate or distribute the weaker characteristics of wood, which gives a more homogeneous product whose mechanical properties are improved in comparison to traditional sawn timber. Higher quality, resistance and dimensional stability can be obtained with engineered wood. In this paper, the word timber is used to define wood used as a building material. Inspired by 
the traditional use of timber from the beginning of the century in many countries where trees were transformed into single-house structural pieces, modern engineered wood products have pushed boundaries in terms of use, strength and structural possibilities. Pieces from smaller trees glued together are now offering more building options. Nowadays, timber used as a structural material is a growing market [1-3]. This growth is partly explained by timber's carbon sequestration abilities and its contribution to sustainable development [4].

Although the use of timber as a structural material has increased in multi-story family and non-residential buildings, it is still not as common in practice. There exists a variety of studies aimed at estimating the market share of tall and large structural timber buildings. The most recent data indicate that in Canada timber is selected between $18 \%$ to $24 \%$ of the time for structural uses [1-3,5-7]. The existence of barriers preventing a massive use of timber as a structural material for multifamily and non-residential buildings, has been demonstrated and most have been identified. Gosselin and al. [7] through a methodical use of extant literature, have shown these barriers to be divided into six categories: code implementation, technology transfer, costs, material durability and other technical aspects, culture of the industry and material availability.

Since the fifth barrier category does not seem to have been fully addressed and since an industry's culture has an impact on innovation adoption, this paper focuses on the "Culture of the industry." This expression is defined by the social behaviours and norms found in the timber building industry. They minimally include the relationships between stakeholders of structural timber building supply chains, stakeholders' respective knowledge and their experience gained through time and projects. The first objective of this research is to identify and characterize the relationships developed between stakeholders in the supply chain for structural timber building projects. The purpose was also to identify enablers for the use of timber as a structural material. Interviews, participant observation and secondary data analyses suggest that the number of relationships developed during a construction project tends to be multiplied when using timber as the structural material while highlighting how networking, collaboration, procurement modes and prefabrication enable its use. Therefore, even though the supply chain structure for timber buildings is well-known, the interrelationships between stakeholders represent a great research opportunity.

The paper examines these interrelationships as follow. First, the construction supply chain is defined and detailed. Subsequently, the methodology used to identify and characterize the relationships developed in a project involving timber is presented. Results follow and are then discussed before concluding.

\subsection{Defining a Construction Supply Chain}

To define a construction supply chain, it is interesting to examine the supply chain management concept (SCM). This concept came about in the 1980s. It suggested a new way of thinking to enable better performance of the supply chain by "managing the associated relationships to deliver value, through innovation and continuous improvement" [8-14]. In 1985, Porter [15] developed the concept of "value chain" with an underlying idea that members of a chain should focus on delivering value from their combined activities. Indeed, members of a value chain share relationships in order to deliver increased value. In this paper, the term "supply chain" will be used. According to Meng et al. [16] supply chain relationship models were first developed in the purchasing and supply sector in the mid-1990s and were then integrated into the construction industry.

Multiple studies have been carried out in response to reports strongly criticizing the construction industry in the UK [17-21]. The largely sequential approach used in a construction project typically supports a lack of integration between design, construction and maintenance methods, leading to inefficiencies, inferior value and poor margins [22]. Attempts were conducted to improve the performance of the SCM but challenges remain in the adoption of the proposed methodologies and concepts, often associated with a lack of new and more systematic approaches to its implementation [23]. Furthermore, trying to demonstrate the effect of relationship management on 
project performance in construction, Meng [24] found that the deterioration of relationships between project parties may increase the likelihood of poor performance.

Many studies have been conducted on the factors influencing the construction supply chain, looking at better supply chain integration, strategic partnerships and collaborative agreements between supply chain actors [22,25-27]. Some authors highlighted the fact that supply chain management, partnerships and collaborative work have partly been adopted by the industry as a means to improve relationships and thus performance among stakeholders [28-31]. Few studies have aimed at describing the relationships that are developed within the supply chain itself. For instance, Akintoye and Main [30] demonstrated that UK contractors share collaborative relationships to develop the construction sector. Meng et al. [16] suggested eight criteria to evaluate the maturity level of a construction supply chain: procurement, objectives, trust, collaboration, communication, problem solving, risk allocation and continuous improvement.

Procurement was identified as a key criterion since it heavily affects the construction supply chain. The type of contract procurements or project delivery system under which a construction project is completed certainly influences and often defines the relationships involved in the supply chain. Many types of contract procurements co-exist in the construction industry around the world. Kantola et al. [32] argued that the "most traditional and commonly used project delivery system worldwide is the design-bid-build system." This mode is mainly characterized by the linearity of the scheduling process and the separation of the design and the building steps. Figure 1 was presented by Broft et al. [33] to visualize the current procurement structure in the construction industry.

Following the linearity of the main procurement mode, from concept design to construction, the building project goes through many construction phases. Behera et al. [14] proposed the Figure 2 to represent these phases in a typical construction project.

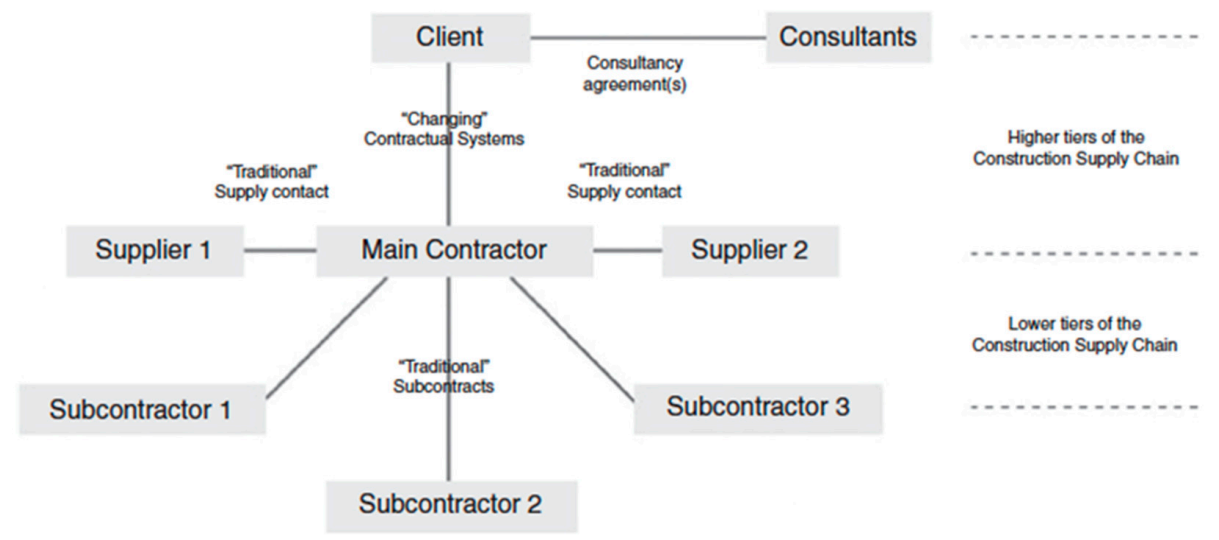

Figure 1. Current procurement structure (Broft et al. [33]; reprinted with permission: Emerald).

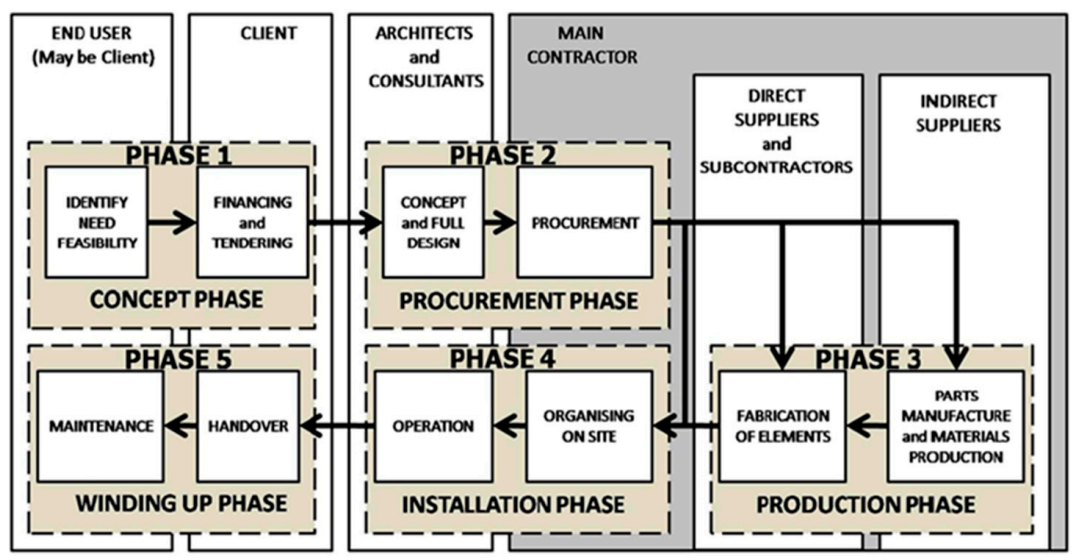

Figure 2. Phases in a typical construction project (Behera et al. [14]; reprinted with permission: Taylor and Francis). 
Some years before, Klein [34] studied facade designing of buildings and their construction process using this model-see Figure 3.

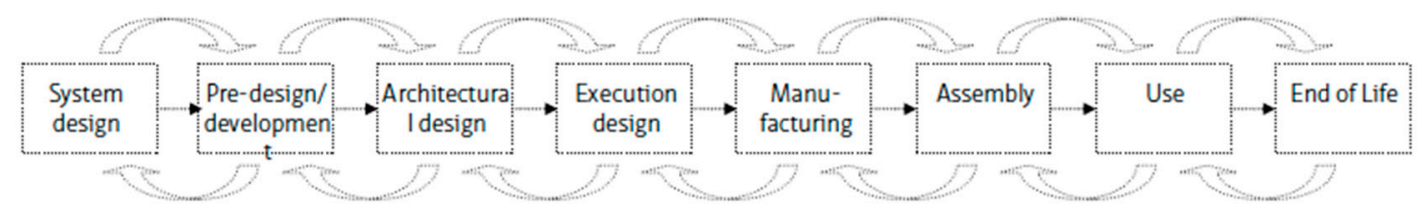

Figure 3. Design and construction phases of a curtain wall (Klein [34]; reprinted with permission: Klein).

The back and forth arrows seen in this figure can be partially explained by the information sharing during the construction process but also by all kinds of interactions occurring between stakeholders. To complete a building, many actors must work together or at least share information, knowledge, work time, material and money. Figure 4, suggested by Hui [35], represents and attempts to explain the situation. It shows the information exchange between parties throughout a building project.

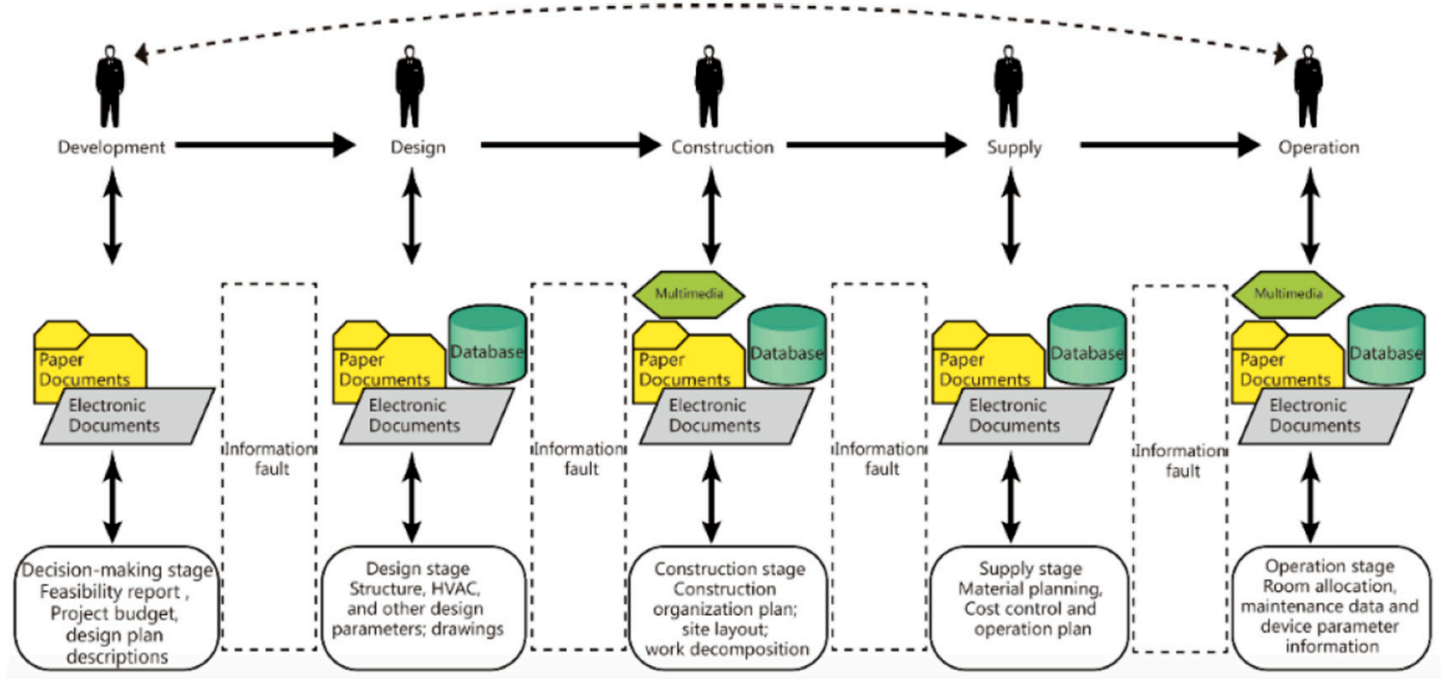

Figure 4. Traditional building information value chain model (Hui et al. [35]; reprinted with permission: IOP PUBLISHING, LTD).

\subsection{Defining a Typical Structural Timber Building Supply Chain}

Therefore, the literature suggests that a typical construction supply chain has mostly been studied and mapped from a linear perspective that includes many stakeholders and encapsulates various relationships. Behera et al. [14] stated that: "The typical supply chain for any given construction project could include architects and engineers, main contractors, specialty subcontractors and timber elements suppliers that come together one time to build a project for a specific owner." Based on these figures and a list of stakeholders from Behera et al. [14], this article proposes the following representation of a typical structural timber building supply chain, illustrated in Figure 5.

Figure 5 represents an international typical supply chain for a timber building where the timber structure is either a light frame or massive timber building system. A typical structural timber building supply chain can integrate either six or five stakeholders depending on the construction mode. These two options are represented in Figure 5. Typically, a real estate developer needs an architect to design the building and an engineer to draw and calculate the structure. Another contract is given to the main contractor who will hire a variety of sub-contractors integrating a builder. Ultimately, a last contract is given to a structural timber element supplier to produce the timber elements needed for the structure (left path). In fact, from the main contractor, the project will either go left (path with 6 main stakeholders) or right (path with 5 main stakeholders) because in some cases the main contractor hires 
a supplier also offering building services. The next section presents the methodology used to study the structural timber building supply chain.

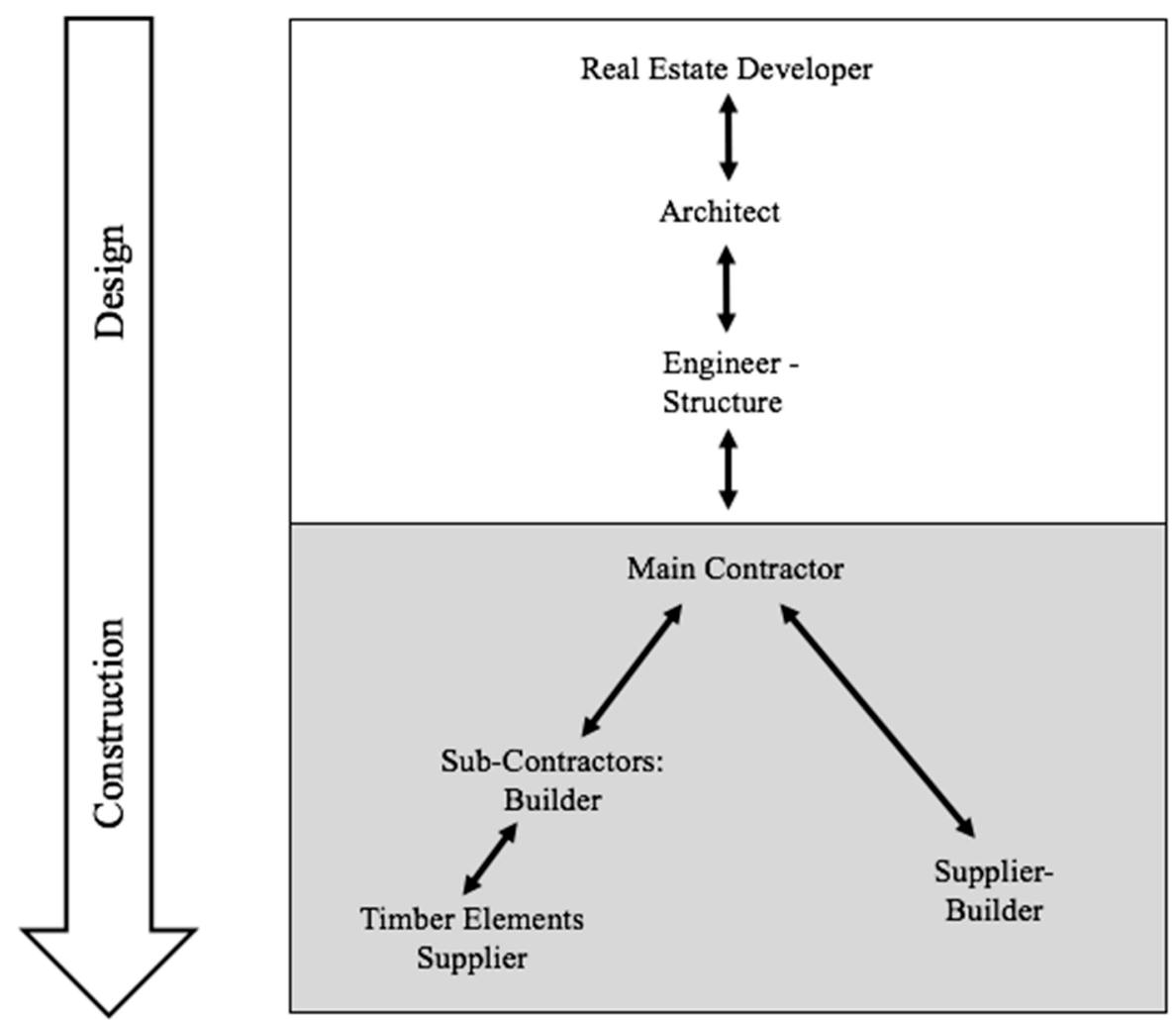

Figure 5. Typical structural timber building supply chain.

\section{Methodology}

This study was conducted to answer the two following questions. What are the relationships involved in structural timber building supply chains? What would facilitate greater use of timber as a structural material? The hypothesis is that relationships are numerous and an important aspect when building with timber structures but their exact influence is not yet known.

\subsection{Research Design and Data Collection}

This research is embodied into the positivist and post-positivist paradigm thus in a logical-deductive and grounded theory form [36]. A multi-method data collection procedure was used to seek an answer to the previous questions. Interviews, participant observation and secondary data were the three methodological tools used. The interview sample will first be presented and then the details of the interviews will be given. Information about participant observations will also be provided. Finally, the associated secondary data used to complete the dataset will be detailed. The section concludes with some explanations about the data analysis that was conducted.

\subsubsection{Sample}

Since the research addressed structural timber building supply chains, the first step was to determine the sample of timber buildings to consider. Tall and large timber buildings made with timber structures was the first criteria. Fifteen well-known timber buildings in Europe were selected based on the level of information available on these projects. An effort was made to diversify the sample and include different types of buildings: multi-story, cultural centres, as well as institutional and offices buildings. However, the sample includes a majority of multi-family buildings. The sample also contains more buildings constructed with massive timber as opposed to light frame systems. 
Then the architects, engineer, builders and engineered wood product suppliers that contributed to these timber building projects were identified. The actors were contacted by e-mail, through personal contact information found on LinkedIn, a professional social network and with help from the responders themselves. Following this process, twelve interviews were scheduled. A snowball sampling technique was used to reach a second wave of key players and set up more interviews [37]. Fortunately, chains bring stakeholders together and they end up knowing members of most of the other companies in their area. Companies that had worked on other timber structural buildings were referenced and integrated into the sample. In the end, the list of supply chain actors contacted had worked on a more diversified sample of timber structure buildings than those listed in Table 1. All companies met appear to be leaders in the field since they are among the first to use timber structures to erect a building. Altogether, sixty-five companies were contacted and asked to participate in this study while twenty-seven agreed. As presented in Table 2, the sample included nine architects, six structural engineers, three builders, three engineered wood product suppliers, three suppliers-builders, one wood board supplier and two timber building technology developers. Seven members of the Wood Sciences department or the equivalent from four universities were also interviewed.

Table 1. Selection of timber structure projects used to initiate contacts with supply chain members.

\begin{tabular}{cccc}
\hline Building Number & Building Name & Country & Type of Building \\
\hline 1 & Tamedia Headquarters & Switzerland & Offices \\
2 & Esmarchstrasse 3 & Germany & Multi-family \\
3 & H8 Bad Aibling & Germany & Multi-family \\
4 & Lifecycle Tower One & Austria & Offices \\
5 & Stadthaus Murray Groove & England & Multi-family \\
6 & Bridport House & England & Multi-family \\
7 & Limnologen & Sweden & Multi-family \\
8 & Via Cenni & Italy & Social housing \\
9 & Forté Building & Australia & Multi-family \\
10 & Treet & Norway & Multi-family \\
11 & Vorway & Library \\
12 & City Academy & England & School \\
13 & Dalston Lane & England & Multi-family \\
14 & Dougrie Drive & Scotland & Social housing \\
15 & Tennishall Södra Climate Arena & Sweden & Tennis hall \\
\hline
\end{tabular}

Table 2. Number of supply chain actors interviewed per category.

\begin{tabular}{cc}
\hline Expert Categories & Number of Interviews \\
\hline Architects & 9 \\
Structural engineers & 6 \\
Builders & 3 \\
Timber elements suppliers & 3 \\
Suppliers-builders & 3 \\
Timber board supplier & 1 \\
Timber building technology developers & 2 \\
\hline
\end{tabular}

The number of respondents was determined by the principle of data saturation, which stipulates that samples are complete when they no longer generate new and relevant information to current research $[38,39]$.

\subsubsection{Semi-Structured Interviews}

Three months between mid-February and mid-May 2017 were spent in Europe to visit every respondent at their office and conduct interviews. Semi-structured interviews were the first methodological tool used to conduct this study. They were formal and individual. For this type 
of interview, meetings were scheduled with the interviewees. The interviewer asked open-ended questions designed to enable the interviewee to express his or her feelings and interests. Each new question was adapted to the answers given by the informant to deepen the subject knowledge and to better understand the information [40]. During the interviews, the investigator's goal was to orient the discussion ensuring it remained connected to the research themes. The interviews were centred around two major themes: Previous experience working on a specific timber building and relationships involved in the process. Each theme was broken down into different variables. The first variables were the enablers and difficulties related to the interviewee's experience of working on one or two specific timber buildings. This way it was possible to understand whether relationships were part of the drivers or constraints to the use of a timber structure in the buildings discussed. The other variables were linked to the business model, strategic vision and actions of the organizations. The questions were based on three elements composing a business model as described by Osterwalder et al. [41]: Customer relationships, channels and key partners. The information gathered from the interviews was completed by participant observation and secondary data.

\subsubsection{Participant Observation}

Participant observation is a tool used to understand social phenomena and its mechanisms by seeing it from the inside. The idea is to enter the studied area and to get as close as possible to its actors [42]. As previously mentioned, three months were spent in Europe to visit twenty-seven companies in nine European countries either in their respective offices or in buildings they had constructed. Some engineered wood product plants were also visited.

\subsubsection{Secondary Data}

To complement information, secondary data was also gathered. Using unpublished data can provide golden information but has to be collected rigorously [43]. It was done before, throughout and after the stay in Europe although written and indexed information was rather difficult to find. Before every meeting, the organization website that was to be met was visited as well as other webpages in order to contextualize the coming interview and buildings that were to be discussed. Also, some company reports and technical booklets were given by representatives of the companies themselves. When needed, more information could be found on the internet after the interview.

\subsection{Qualitative Analysis}

To analyse the data, a qualitative approach was adopted. Qualitative data analysis is based on everyday life experience and on common sense. According to L'Écuyer [44], this method consists of describing the specific characteristics of different elements (words, phrases, ideas, etc.) grouped together into categories, which emerge in addition to their quantitative meanings. The essence of the phenomenon studied resides in the nature and in the very specific content of the material analysed, rather than only in its quantitative characteristics.

Qualitative analysis is the main thread of content analysis in its search for meaning. It consists of a careful description of the various particularities which emerge from the compilations [45-49]. Comprehensive field notes were taken while conducting the interviews. Notes were about the interview content and about the observations made in the offices, plants and buildings visited. These field notes were complemented with information from secondary data. Therefore, twenty-seven field note resumes were written during the field work. Content analysis of field notes and secondary data was rigorously conducted to ensure reliability and validity of results [50,51]. A systematic procedure was followed to ensure the credibility of the research [52]. According to the research variables described earlier, a code system was established and coding was performed [53]. Three types of relationships were found: contractual, project related and for industry development. They are presented in the following results section. 


\section{Results}

In this section, results of the interviews, participant observation and secondary data are presented. The relationships that occur among the stakeholders when working on the completion of a timber structural building and within the structural timber building industry are identified and characterized.

\subsection{Relationships between Stakeholders in a Structural Timber Building Supply Chain}

The data collected for this study clearly illustrated how innovating and building with a timber structure requires a multitude of strong relationships. The literature mentions the third tier of the construction supply chain as having been the most investigated, while research across the upper two tiers has been limited [54]. However, it has confirmed that providing longer-term stability between the various parties brings benefits [28]. The observed relationships were divided into three levels of interactions. The first level was called the "contractual (C)" level, since they are mandatory exchanges for the construction of a building. They are linked to the contracts themselves therefore such relationships occur in every building project. The second level of relationships corresponds to the "timber building project $(\mathrm{P})$ " level. As explained below, they mainly exist to compensate higher risks and uncertainties involved when building with a timber structure. The third level of relationships refer to the "development of the structural timber building industry (I)" since they exist to popularize the structural timber uses in construction. The relationships between stakeholders of structural timber building supply chains discovered through this research are represented in Figure 6.
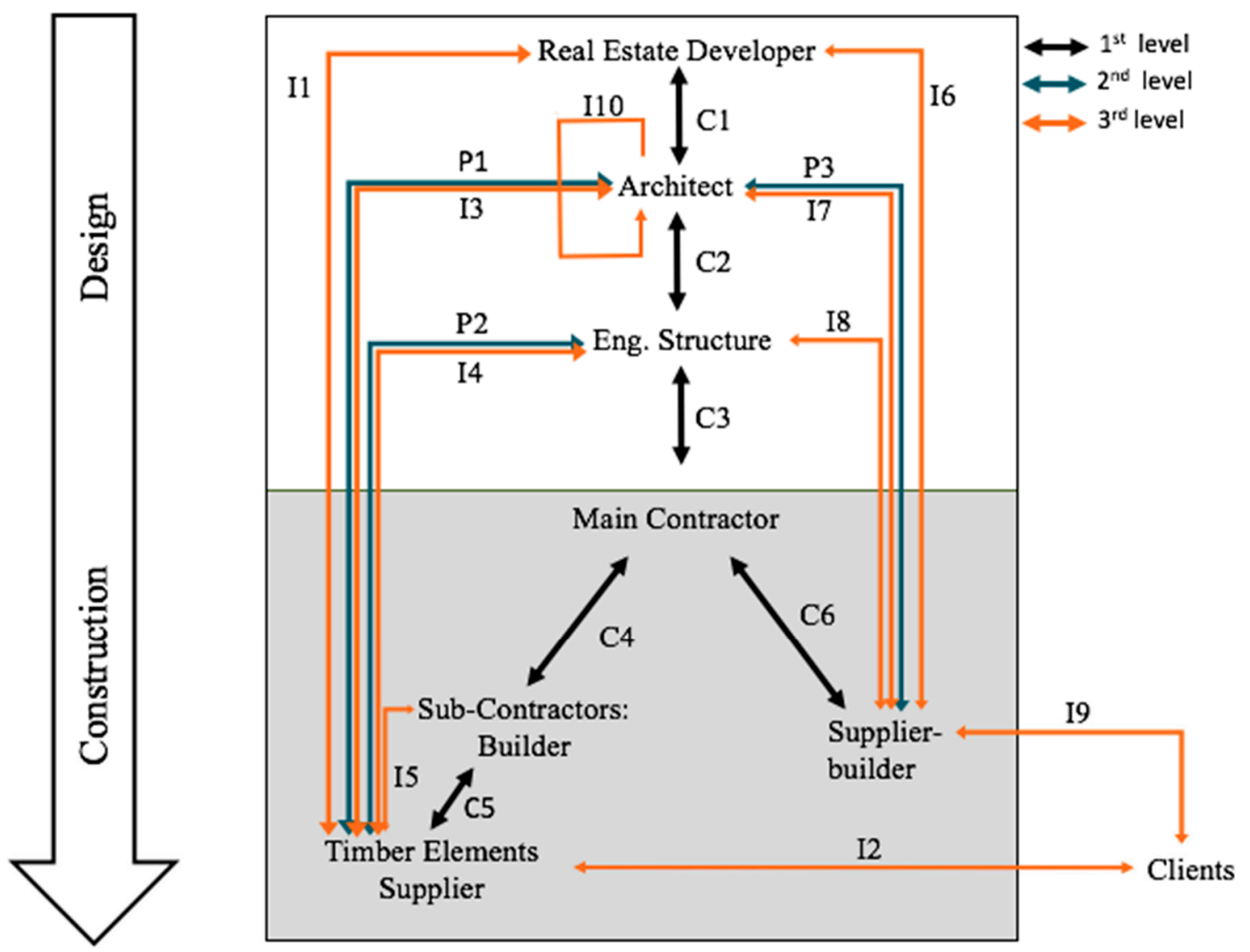

Figure 6. "Contractual (C)," "timber building project $(\mathrm{P})$ " and "structural timber building industry development (I)" relationships involved in a structural timber building project.

\subsubsection{First Level_“Contractual (C)” Relationships}

Results indicate that "contractual (C)" relationships coexist throughout the supply chain of the timber structural construction industry. The black arrows in Figure 6 represent the relationships 
developed between members of a typical structural timber building supply chain. C1-the real estate developer will need an architect to conceive and design the building he has in mind; C2-then the architect needs an engineer to make sure the design proposed will be structurally sound and to draw the structure in detail; C3-the main contractor will receive the plans conceived by the architect and the engineer; C4-the main contractor will need a builder to build the structure; C5-the builder will need to find some timber building material. The supplier is there to produce and provide it; For the five stakeholders structural timber building supply chain path mentioned earlier, C6-the supplier integrates the building service into its value proposition. The supplier-builder will then use the plans provided by the main contractor to erect the structure using their own material. Again, these relationships occur in every building project no matter which structural building material (concrete, steel or timber) is used.

\subsubsection{Second Level—“Timber Building Project $(\mathrm{P})$ ” Relationships}

The interviews revealed the need for more involvement from stakeholders in the building process when it came to a timber structure. Additional relationships therefore become part of the model. Referring to the law of diffusion curve developed by Rogers [55], they seem to mainly exist because structural timber buildings are in the early phase of innovation adoption—see Figure 7.

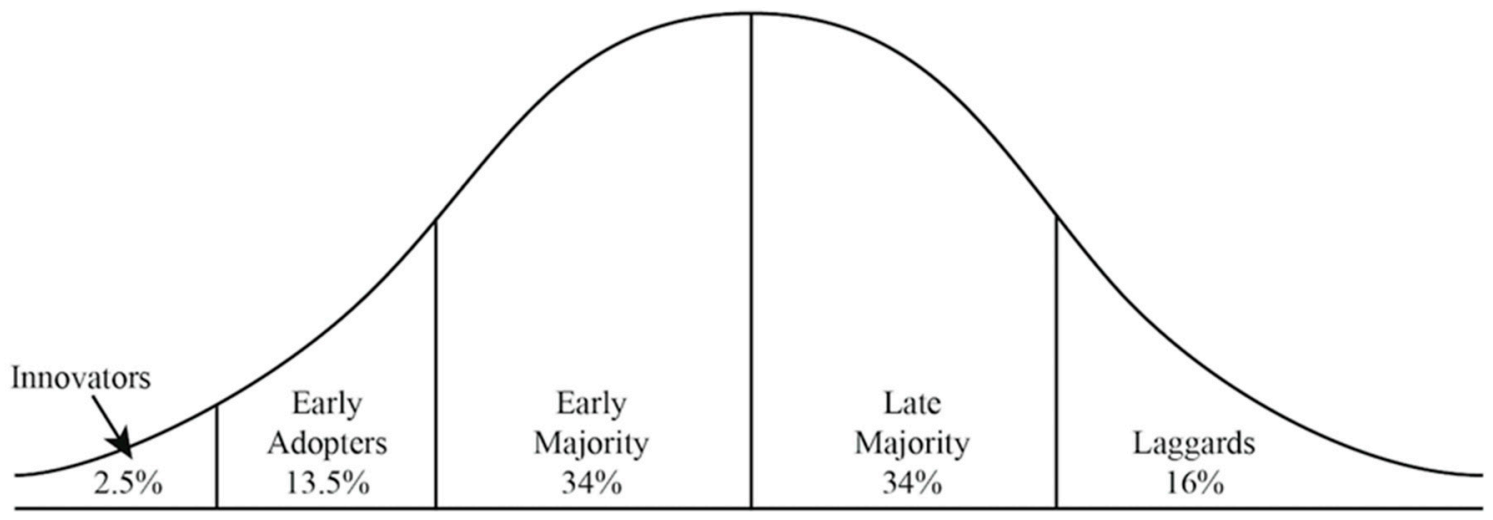

Figure 7. Law of diffusion curve, adapted from Rogers [55].

In 1962 Rogers came forth with his seminal work on the diffusion of innovations which studies individuals and their social systems in relation to the adoption of innovations. An innovation can be seen as an idea, practice or object new to someone [55]. The process of adoption then becomes the mental process by which the individual will materialize this idea or practice. According to Rogers [55], "diffusion is the process by which an innovation is communicated through certain channels over time among the members of a social system." Communication is a "process in which participants create and share information with one another in order to reach mutual understanding." Since any innovation integrates risk and uncertainty, individuals attempt to reduce them by obtaining information from each other. This is what currently happens throughout the supply chain of a structural timber building. Since building with a timber structure is still new and not yet standardized, stakeholders share information in order to protect themselves, reduce risks and uncertainties. In fact, construction innovations are strongly influenced by industry relationships [56,57]. Dubois and Gadde [56] describe the relationships in construction as 'loose couplings.' This describes the temporary coalitions of firms and individuals that come together to complete a project and then disband. Also, Blayse et al. [58] explain the situation: "The importance of relationships lies in their capacity to facilitate knowledge flows through interactions and transactions between individuals and firms."

"Timber building project $(\mathrm{P})$ " relationships are represented by the blue arrows in Figure 6. A special link exists between architects and suppliers and another between the structural engineers and the suppliers. A relation between an architect and a supplier-builder was also pointed out by the interviewees. 
P1-Relations between Architects and Suppliers

From the data collected, the need for a supplier's early involvement in the structural timber building supply chain was obvious. One said: "we were involved in the project very early so that we could assess the engineers and the client and the other parties early on with our expertise in timber engineering and timber installation" (A016). Since engineered timber is a fairly new product and not everyone is used to working with it, suppliers want to be involved in the design phase even if it represents an additional cost: "we participated in those meetings and in that creative phase without getting paid" (A016). By doing so they want to ensure that the architects will design their buildings having in mind the possibilities or particularities offered by structural timber products: "if they told the engineers and architects that you have to make the plans without any influence of any supplier or installer at all, then it would have been very likely that the design would have been too expensive or maybe too risky to price because we don't know the plants good enough or well enough" (A016). Like any other building materials, timber will enable some shapes and key attributes while making some others more difficult. If the suppliers are involved in the concept design phase, less plan corrections and back and forth communication between the design team and the suppliers are likely to be needed thus saving time and money.

\section{P2-Relations between Structural Engineers and Suppliers}

It was the same case with the structural engineers and suppliers. As expressed by the quotes in the previous paragraph, suppliers also want and need to be in touch with the structural engineer early in the process. Here is another important point to understand when building with timber: two structural engineers are often involved in a construction project. The structural engineer for the project, part of the design phase, will be responsible for the structural design of the building. The suppliers are responsible for the production of the structural elements designed by these structural engineers. To do so, the supplier teams usually integrate another structural engineer. In some cases, technicians are responsible for the production based on plans signed by an engineer. When the suppliers are asked to produce the specified elements for a specific building, they will do so in accordance to the structural plans transferred by the structural engineer from the design phase. Usually the two engineers will exchange until they reach an agreement. Most of the time, the engineers working for the suppliers have the most experience related to their installations and are aware of production capabilities and therefore need to transfer this knowledge. This is to ensure that the structural elements suggested by the structural engineer are producible. The structural engineer for the project will then have to respect these specifications. These common steps or adjustments explain why suppliers are sometimes involved in the design phase meetings and process.

"Along the way, the intention was that we were going to be the supplier of the main numbering system. So we participated in those meetings and in that creative phase without getting paid but knowing that if this project becomes a reality, then we will get the contract. [ ... I It is good because if they hadn't done it like that, if they told the engineers and architects that you have to make the plans without any influence of any supplier or installer at all, then it would have been very likely that the design would have been too expensive or maybe too risky for [... ] and other companies to price because they don't know the plants good enough or well enough and they would have thought that they'll be okay. [ ... ] Then the project would maybe not be realized" (A018).

The behaviour of these suppliers contradicts the literature's view of normal construction project interactions. The examples of supplier involvement in the early stages of projects go against the idea of highly adversarial and fragmented approaches to relationships often present in the construction supply chain $[18,59,60]$, which is interesting to point out.

P3-Relations between Architects and Supplier-Builders

This type of relationship is less common meaning they occur less often. Some architects might have ideas at the concept stage and not be sure about what pieces of timber could be produced by a given supplier. To get to know each other, these two stakeholders can meet to discuss the possibilities. 
A very interesting case revealed by this study is where an architect visited the supplier-builder plant to find a solution to produce a beam which the supplier had refused to do. "Through the process, I went to [ ... ] to discuss those beams because in the beginning, they couldn't do it. [ . . ] and when I left in the afternoon, it was possible" (A021). Together, they finally found a solution and the beam was produced. This specific example shows how more involvement from the stakeholders can favour timber use.

Relationships occurring on specific structural timber building projects have been noted. Data also reveals other relationships between stakeholders allowing the development of the structural timber building industry.

\subsubsection{Third Level—“Structural Timber Building Industry Development (I)" Relationships}

The "structural timber building industry development (I)" relationships are represented by the orange arrows on Figure 6. To develop their markets, suppliers and supplier-builders need to work on customer relationships. Mainly through their marketing strategies, participation to conferences, respective websites, media presence, private customer relationships and visits, the suppliers appear to create links with most members of the supply chain. Results demonstrate that the suppliers try to connect with real estate developers: I1-Relations between the suppliers and the real estate developers. End-users, future building or apartment renters thus clients, are also part of the supplier's marketing strategies. These actors can influence the selection of timber as the preferred material and the suppliers would like to convince them that timber is the best material to use in many cases: I2-Relations between the suppliers and the clients. Architects and engineers, the concept actors, are also reached by the suppliers to make sure they learn about new timber constructive systems: I3-Relationships between suppliers and architects and I4-Relationships between suppliers and engineers. Same as with the builder: 15-Relationships between suppliers and builders, this relationship implies a lot of knowledge transfer to builders about how to build the structure. Timber involves new ways of working and builder employees can be overwhelmed by new work methods or by the implementation of different processes. The following quote might explain why some suppliers integrate the building services into their value proposition: "The challenge is to convince the entrepreneurs to try new things. And it's all timber buildings. They don't know how to do it and they give a little bit higher price. So it's more expensive because they don't know how to do it." (A019).

Similarly, in order to develop their markets, supplier-builders will establish relationships with the real estate developers, the architects and the structural engineers. The real estate developers need to learn about timber buildings: I6-Relations between suppliers-builders and real estate developers. For optimum design, the architect should be aware of the specifications offered by the timber supplier-builder plant. When this information is shared, it can substantially simplify the intersection between the concept and the construction phases: I7-Relations between supplier-builders and architects. As explained earlier, the engineers responsible for the design of the building should know the supplying plant's capabilities before designing and detailing a structure to save time, effort and energy: I8-Relations between supplier-builders and engineers. The supplier-builders will also need to sell their products and services to the clients. Potential clients of new buildings will also be targeted by the marketing plan of the supplier-builder: I9-Relations between supplier-builders and clients. For one of the supplier-builder companies studied, producing and delivering a highly specialized product and service means that the clients come by themselves. This is the case of a company prefabricating building modules. Clients are aware of these products and word spreads without unfolding any marketing strategy.

Relations between architect's professional corps themselves have also been witnessed: I10-Relations between architects. The nature of this relationship is a bit different. It occurs within the same stakeholder category. The interviews revealed a situation where a leading architecture firm specializing in structural timber building offered timber building design training to other architect firms. "Last week, it was the company from [ ... ], an architect office. They phoned and wanted to come down to learn. We take money for doing that-they have to pay" (A019). Another architect firm also mentioned the 
tendency to get together and help each other when designing for timber. Although this firm is leading the field, they do not fear sharing their knowledge. Their objective is to see timber building market shares grow and not simply remaining the best.

\section{Discussion}

In this section, elements seen as facilitators to the increase of timber use as a structural material will be discussed. Data collected made clear that stakeholders entering the structural timber building field need to adopt a new cultural mindset. The relationships involved in structural timber building projects are closer to a network than a linear chain. Relationships shared are also closer to collaboration than simple transactional relationships. Some procurement methods facilitating the use of timber as a structural material and prefabrication can be seen as a way to diminish the number and complexity of the relationships and thus, act as an accelerator to the use of timber as a structural material.

\subsection{A Cultural Mindset Switch Is Needed}

The culture of the construction industry needs to keep changing if timber used as a structural material is to become more popular. For instance, Akintoye et al. [25] showed that partnership/collaboration agreements between contractors, suppliers and clients are more common but they also referred to workplace culture as a barrier to partnerships/collaboration in the implementation of SCM. Following this idea, the construction industry culture is limiting partnerships and collaboration within the timber construction value creation chain. Although many legal aspects cannot be changed easily, the way the supply chain's actors behave can be modified. In his book, Morgan [61] explains that organizations have their own cultural contexts, "system of knowledge, ideology, values, laws and day-to-day ritual." The industry should be able to see a value network rather than a linear chain while thinking "collaboration" rather than simple relations transactions. These two deductions are explained in the following paragraphs.

\subsubsection{From the Linear Construction Supply Chain to a Value Network}

"Supply chains are so called because they describe a process where companies communicate with each other in a linear manner" [62]. The arrow network represented in Figure 6 indicates how stakeholders do not always follow a linear mode in their interactions. In fact, communication and relationships between the actors look more like a network than a linear chain. For instance, London et al. [54] insisted on the fact that the majority of parties taking part in a construction project "is largely a network of small to medium enterprises" based on network sourcing concepts and "aiming to foster risk sharing and engender stability in contractual chains." Tennant et al. [63] pointed out the existence of a less studied hybrid form of organizational governance, clans. According to Ouchi [64], clans would take form in "technologically advanced or closely integrated industries, where teamwork is common, technologies change often and therefore individual performance is highly ambiguous." To be able to cope with the unknown technology development rates and technology interdependencies involved in the building industry, multi-technology firms-the architects, the engineers, the main contractors, the builders and the timber elements suppliers-need to maintain "loose couplings networks" meaning close relationships to ensure they will have access to equipment, components and specialized knowledge when needed [65]. Overall, since risks, uncertainties and unavailable information are common when using a timber structure, networking should be favoured. Prefabrication helps preventing those difficulties and it is discussed in the Section 4.3.

\subsubsection{From Simple Relations ... to Collaboration}

As stated before, building with a timber structure is still new to the industry or at least its adoption is still in its early phase. The interviews have shown how deep communication and interactions is needed in the building process when using structural timber and how there is in fact a need for collaboration to innovate. Stakeholders of the structural timber building supply chain or value 
network seem to collaborate rather than simply interact. As mentioned in the literature and in the first part of the article, collaboration is needed which is not new to the construction industry. Many studies have been conducted on partnering and collaboration. Barratt [66] suggested that a supply chain where customers buy services is an appropriate context for collaboration. The literature demonstrates a tendency to focus on project partnering between clients and contractors as well as on formal tools to develop these relationships [31]. Meng [67] proved that: the "UK construction industry as a whole has experienced an important change and moved toward supply chain collaboration." However, the construction industry context makes it unlikely for partnering to reach outside the project level. As Gadde et al. [68] argued: "Taking the step to strategic partnerships would require modification of some of the basic assumptions and norms of industry efficiency." In fact, collaboration is easier to accomplish when the procurement strategy allows it, meaning when the design and the construction phases are led simultaneously. Even here collaboration is first and foremost a story of human behaviour and we are witnessing the emergence of many tools to facilitate it: Building Information Modelling, lean manufacturing and prefabrication to mention only them.

\subsection{Some Methods for Awarding Contracts Facilitate Collaboration and Innovation}

When actors in the construction phase are involved in the concept or the design phase, the relationships developed are more likely to become collaborative. Design-Build for instance will increase proximity in a project [69]. Rosner et al. [70] demonstrated that performance is significantly better in terms of cost growth and the number of modifications per million dollars when using Design-Build compared to the traditional Design-Bid-Build contract type. The Swedish "Total entreprenor" contract type used in the Scandinavian area also favours collaboration. Procurement systems is one of the six main factors identified that influence innovation in the building and construction industry [58,71]. In fact, it has been demonstrated in the literature that the more innovative a project is, the less traditional contract procurement modes are needed. For example, Traditional modes do not help LEED or Zero energy 1 innovative philosophies [32].

\subsection{Prefab: A Collaboration Accelerator}

Some of the actors met have chosen to enter the prefabricated light frame or massive timber structural systems product market. Decreased construction times and increased quality are the main advantages of prefabricated systems in the construction industry [72-78]. Waugh [79] specifically mentioned how construction projects using Crossed Laminated Timber (CLT) as the structural material allow field times to be reduced if compared to the use of concrete and steel. Cox et al. [75] listed the following obstacles to prefabricated systems in the construction industry: "poor current education within the industry regarding prefabricated practices, the archaic nature of the industry lacking trust, reluctance to embrace new and innovative techniques and the absence of a proven holistic and encompassing evaluation technique to provide accurate and reliable comparisons between differing construction methods."

From the sample, it also appears that prefabrication in the building sector can be viewed as a collaboration enabler. If a company decides to incorporate building services into its value proposition, the number of actors involved in the supply chain becomes limited and collaboration can be optimized with client relationships existing within the same entity. Collaboration within the same organization is probably easier than between two companies from the same supply chain. Asad et al. [80] pointed out that "innovative thinking across the supply chain can offer the clients and service providers key benefits in terms of adaptability, financial growth and improved service delivery." Thus, prefabrication seen as innovative thinking could favour the structural timber building industry.

\section{Conclusions}

To summarize, this research demonstrated the numerous relationships involved in the structural timber building supply chain. Existing and possible collaboration patterns were demonstrated. 
The most striking collaboration example is the need for timber elements suppliers to establish relationships with all members of the value chain to familiarize them with their products and increase their use. The specific relationships emerging between timber elements suppliers and project engineers are of utmost importance. As timber construction is revitalizing but is still not a common practice, these two stakeholders need to strengthen their collaboration to better understand each other and share on production possibilities and project design options. This collaboration ensures the best structural results for projects. Collaboration relationships were divided into three levels. 1-Contractual, 2-Timber building project and 3-Structural timber building industry development relationships. The first two levels are well defined; their nature is respectively legal and based on projects. Level 3 relationships aim towards better timber structural material adoption and utilization because they imply knowledge transfers and strengthening of expertise. The results have shown the cultural transition needed in the timber building industry: Thinking about a value network rather than a linear chain and favouring collaboration between members of the network rather than simple transactional relationships. The results also demonstrated contract procurement modes where stakeholders from both phases, design and construction, work closely together from the beginning to the end of the project better suit the structural timber building industry. Finally, in the timber building projects studied, the use of prefabricated elements and modules facilitated project erection and realization. These systems are facilitators to the growth of the structural timber building industry since they limit the numbers of stakeholder relationships involved in the construction process and bring collaboration within the same organization. Further research could aim to identify pathways to establish and improve these collaboration relationships. Good examples could be extracted from other building material industries.

Author Contributions: A.G., P.B., N.L. and Y.C. conceived and designed the experiments; A.G. performed the experiments; A.G. analyzed the data; A.G., P.B., N.L. and Y.C. contributed reagents/materials/analysis tools; A.G. wrote the paper.

Funding: This research was funded by Natural Sciences and Engineering Research Council of Canada through its ICP and CRD programs (IRCPJ 461745-12 and RDCPJ 445200-12) as well as by the industrial partners of the NSERC industrial chair on eco-responsible wood construction (CIRCERB).

Conflicts of Interest: The authors declare no conflict of interest.

\section{References}

1. Robichaud, F. L'utilisation du Bois en Construction Non Résidentielle au Québec: Enquête Auprès des Ingénieurs en Structure; FPInnovations: Pointe-Claire, QC, Canada, 2010.

2. Chamberland, V.; Robichaud, F. Le Marché Pour les Bois de Structure Dans la Construction non Résidentielle au Québec; PInnovations: Pointe-Claire, QC, Canada, 2013.

3. Drouin, M. Étude de Marché Pour les Bois de Structure Dans la Construction Non Résidentielle au Québec; PInnovations: Pointe-Claire, QC, Canada, 2015.

4. Frühwald, A. The Ecology of Timber Utilization Life Cycle Assessment Carbon Management etc; Department of Wood Science and Technology, University of Hamburg: Doorn, Germany, 2007.

5. Gaston, C.; Kozak, R.; O'Connor, J.; Fell, D. Potential for Increased Wood-Use in N. A. Non-Residential Markets; Project No. 2711; Forinteck Canada Corp.: Vancouver, BC, Canada, 2001.

6. O'Connor, J.; Gaston, C. Potential for Increased Wood-Use in the N. A. Non-Residential Markets-Part II (Builder/Owner Survey); Forintek Cananda Corop.: Vancouver, BC, Canada, 2004.

7. Gosselin, A.; Blanchet, P.; Lehoux, N.; Cimon, Y. Main Motivations and Barriers for Using Wood in Multi-Story and Non-Residential Construction Projects. BioResour. J. 2016, 12, 546-570. [CrossRef]

8. Christopher, M. Logistics and Supply Chain Management: Creating Value-Adding Networks, 3rd ed.; Prentice Hall Financial Times: Harlow, UK, 2005; 305p.

9. Peck, H. Reconciling supply chain vulnerability, risk and supply chain management. Int. J. Log. Appl. 2006, 9, 127-142. [CrossRef]

10. Pryke, S. Construction Supply Chain Management: Concepts and Case Studies; Wiley-Blackwell: Oxford, UK, 2009; 230p.

11. Blanchard, D. Supply Chain Management: Best Practices; John Wiley \& Sons: Oxford, UK, 2010; 304p. 
12. Van Weele, A.J. Purchasing and Supply Chain Management: Analysis, Strategy, Planning and Practice; Cengage Learning EMEA: Andover, MA, USA, 2010; 418p.

13. Fulford, R.; Standing, C. Construction industry productivity and the potential for collaborative practice. Int. J. Proj. Manag. 2014, 32, 315-326. [CrossRef]

14. Behera, P.; Mohanty, R.P.; Prakash, A. Understanding Construction Supply Chain Management. Prod. Plan. Control 2015, 26, 1332-1350. [CrossRef]

15. Porter, M.E. Competitive Advantage: Creating and Sustaining Superior Performance; The Free Press: New York, NY, USA, 1985; 557p.

16. Meng, X.; Sun, M.; Jones, M. Maturity Model for Supply Chain Relationships in Construction. J. Manag. Eng. 2011, 97-105. [CrossRef]

17. Latham, M. Constructing the Team; Her Majesty's Stationary Office: London, UK, 1994.

18. Egan, J. Rethinking Construction; Department of the Environment, Transport and the Regions: London, UK, 1998.

19. Barker, K. Barker Review of Land Use Planning Final Report_Recommandations; Her Majesty's Stationery Office: London, UK, 2006.

20. Cabinet Office. Government Construction Strategy; UK Government: London, UK, 2011.

21. Farmer, M. The Farmer Review of the UK Construction Labour Model; Construction Leadership Council: London, UK, 2016.

22. Holti, R.; Nicolini, D.; Smalley, M. The Handbook of Supply Chain Management: The Essentials; Construction Industry Reasearch and Information Association and the Tavistock Institute: London, UK, 2000; 95p.

23. Saada, M.; Jonesb, M.; James, P. A review of the progress towards the adoption of supply chain management (SCM) relationships in construction. Eur. J. Purchasing Supply Manag. 2002, 8, 173-183. [CrossRef]

24. Meng, X. The effect of relationship management on project performance in construction. Int. J. Proj. Manag. 2012, 30, 188-198. [CrossRef]

25. Akintoye, A.; McIntosh, G.; Fitzgerald, E. A survey of supply chain collaboration and management in the UK construction industry. Eur. J. Purchasing Supply Manag. 2000, 6, 159-168. [CrossRef]

26. Briscoe, G.; Dainty, A. Construction supply chain integration: An elusive goal? Supply Chain Manag. Int. J. 2005, 10, 319-326. [CrossRef]

27. Rimmers, B. Slough Estates in the 1990s-Client Driven SCM. In Construction Supply Chain Management: Concepts and Case Studies; Pryke, S., Ed.; Wiley-Blackwell: Oxford, UK, 2009; pp. 137-159.

28. Briscoe, G.H.; Dainty, A.R.J.; Millett, S.J.; Neale, R.H. Client-led strategies for construction supply chain improvement. Constr. Manag. Econ. 2004, 22, 193-201. [CrossRef]

29. Wood, G.D.; Ellis, R.C.T. Main contractor experiences of partnering relationships on UK construction projects. Constr. Manag. Econ. 2005, 23, 317-325. [CrossRef]

30. Akintoye, A.; Main, J. Collaborative relationships in construction: The UK contractors' perception. Eng. Constr. Archit. Manag. 2007, 14, 597-617. [CrossRef]

31. Bygballe, L.E.; Jahre, M.; Swärd, A. Partnering relationships in construction: A literature review. J. Purchasing Supply Manag. 2010, 16, 239-253. [CrossRef]

32. Kantola, M.; Saari, A. Project delivery systems for nZEB projects. Facilities 2016, 34, 85-100. [CrossRef]

33. Broft, R.; Badi, S.M.; Pryke, S. Towards supply chain maturity in construction. Built Environ. Proj. Asset Manag. 2016, 6, 187-204. [CrossRef]

34. Klein, T. Integral Façade Construction: Towards a New Product Architecture for Curtain walls; Universiteit Delft: Wesel, Duistland, 2013.

35. Hui, Z.; Weishuang, X. Research on BIM-based building information value chain reengineering. In Proceedings of the 3rd International Conference on Energy Materials and Environment Engineering, Bangkok, Thailand, 10-12 March 2017.

36. Denzin, N.K.; Lincoln, Y.S. The Discipline and Pratice of Qualitative Research. In The Sage Handbook of Qualitative Research, 3rd ed.; Denzin, N.K., Lincoln, Y.S., Eds.; Sage Publications: Thousand Oaks, CA, USA, 2005; p. 1210.

37. Heckathorn, D.D. Comment: Snowball versus respondent-driven sampling. Sociol. Methodol. 2011, 41, 355-366. [CrossRef]

38. Mucchielli, A. Dictionnaire des Méthodes Qualitatives en Sciences Humaines et Sociales; Colin: Paris, France, 1996; $303 p$. 
39. Poupart, J.; Deslauriers, J.-P.; Groulx, L.H.; Mayer, R.; Pires, A. La Recherche Qualitative: Enjeux Épistémologiques et Méthodologiques; Gaëtan Morin: Montréal, QC, Canada, 1997; 405p.

40. Lessard-Hébert, M.; Goyette, G.; Boutin, G. La Recherche Qualitative, Fondements et Pratiques; Éditions Nouvelles: Montréal, QC, Canada, 1995; 124p.

41. Osterwalder, A.; Pigneur, Y. Business Model Generation: A Handbook for Visionaries, Game Changers, and Challengers; John Wiley \& Sons: New York, NY, USA, 2010; 288p.

42. Fortin, A. L'observation participante: Au coeur de l'altérité. In Les Méthodes de la Recherche Qualitative; Deslauriers, J.-P., Ed.; Presses de l'université du Québec: Quebec, QC, Canada, 1987; pp. 23-33.

43. Herbert, J. Using Unpublished Data: Error and Remedies; SAGE Publications: Newbury Park, CA, USA, $1984 ; 65 p$.

44. L'Écuyer, R. Méthodologie de L'analyse Développementale de Contenu: Méthode GPS et Concept de Soi; Presses de l'Université du Québec: Sillery, QC, Canada, 1990; 472p.

45. Silverman, D. Analysing Talk and Text. In Handbook of Qualitative Research, 2nd ed.; Denzin, N.K., Lincoln, Y.S., Eds.; SAGE Publications Inc.: Thousand Oaks, CA, USA, 2008; pp. 821-834.

46. Ghauri, P.; Gronhaug, K. Research Methods in Business Studies; FT Prentice Hall: Harlow, UK, 2005.

47. Lincoln, Y.S.; Guba, E.G. Paradigmatic controversies, contradictions, and emerging confluencies. In Handbook of Qualitative Research, 2nd ed.; Denzin, N.K., Lincoln, Y.S., Eds.; SAGE Publications Ltd.: Thousand Oaks, CA, USA, 2008; pp. 163-188.

48. Saunders, M.; Lewis, P.; Thornhill, A. Research Methods for Business Students; Pearson Education Limited: Harlow, UK, 2012.

49. Bryman, A.; Bell, E. Business Research Methods, 4th ed.; Oxford University Press: Oxford, UK, 2015.

50. Carmines, E.G.; Zeller, R.A. Reliability and Validity Assessment; Sage Publications: Beverly Hills, CA, USA, 1979.

51. Cooper, H.; Hedges, L.V.; Valentine, J.C. The Handbook of Research Synthesis and Meta-Analysis; Russell Sage Foundation: New York, NY, USA, 2009.

52. Johnston, M.P. Secondary Data Analysis: A Method of which the Time Has Come. Qual. Quant. Methods Librairies 2014, 3, 619-626.

53. Miles, M.B.; Huberman, A.M. Qualitative Data Analysis, 2nd ed.; SAGE Publications: Thousand Oaks, CA, USA, 1994; 408p.

54. London, K.; Kenley, R.; Agapiou, A. Theoretical supply chain network modelling in the building industry. In Proceedings of the 14th Annual ARCOM Conference, Reading, UK, 9-11 September 1998.

55. Rogers, E.M. Diffusion of innovations; The Free Press: New York, NY, USA, 2003; 453p.

56. Dubois, A.; Gadde, L.-E. The construction industry as a loosely coupled system: Implications for productivity and innovation. Constr. Manag. Econ. 2002, 20, 621-631. [CrossRef]

57. Miozzo, M.; Dewick, P. Building competitive advantage: Innovation and corporate governance in European construction. Res. Policy 2002, 31, 989-1008. [CrossRef]

58. Blayse, A.M.; Manley, K. Key Influences on Construction Innovation. Constr. Innov. 2004, 4, $143-154$. [CrossRef]

59. Bresnen, M.; Marshall, N. Partnering in construction: A critical review of issues, problems and dilemmas. Constr. Manag. Econ. 2000, 18, 229-237. [CrossRef]

60. Chan, A.P.C.; Chan, D.W.M.; Ho, K.S.K. Partnering in Construction: Critical Study of Problems for Implementation. J. Manag. Eng. 2003, 19, 126-135. [CrossRef]

61. Morgan, G. Images of Organization; SAGE Publications: Thousand Oaks, CA, USA, 1997; 485p.

62. Ledbetter, S. Communicating Down the Cladding Supply Chain; Facade Design and Procurement; Center for Windows and Cladding Technology: Bath, UK, 2003.

63. Tennant, S.; Fernie, S. An emergat form of client-led supply chain governance in UK construction: Clans. Int. J. Constr. Supply Chain Manag. 2012, 2, 1-16. [CrossRef]

64. Ouchi, W.G. Markets, Bureaucraties, and Clans. Adm. Sci. Q. 1980, 25, 129-141. [CrossRef]

65. Brusoni, S.; Prencipe, A.; Pavitt, K. Knowledge Specialization, Organizational Coupling, and the Boundaries of the Firm: Why Do Firms Know More Than They Make? Admn. Sci. Q. 2001, 46, 597-621. [CrossRef]

66. Barratt, M. Understanding the meaning of collaboration in the supply chain. Supply Chain Manag. Int. J. 2004, 9, 30-42. [CrossRef] 
67. Meng, X. Change in UK construction: Moving toward supply chain collaboration. J. Civ. Eng. Manag. 2013, 19, 422-432. [CrossRef]

68. Gadde, L.-E.; Dubois, A. Partnering in the construction industry-Problems and opportunities. J. Purchasing Supply Manag. 2010, 12, 254-263. [CrossRef]

69. Plusquellec, T.; Lehoux, N.; Cimon, Y. Design-Build Framework for SMEs in the Construction Industry. In Proceedings of the CCSBE/CCPME Conference-The Development of SMEs and Entrepreneurship in the New Context of Globalisation, Quebec, QC, Canada, 11-13 May 2017.

70. Rosner, J.W.; Thal, A.E., Jr.; West, C.J. Analysis of the Design-Build Delivery Method in Air Force Construction Projects. J. Constr. Eng. Manag. 2009, 135, 710-717. [CrossRef]

71. Blayse, A.; Karen, M. Influences on Construction Innovation: A Brief Overview of Recent Literature; The BRITE Project-Building Research, I., Technology, Environment; Cooperative Research Centre for Construction Innovation: Brisbane, Australia, 2003.

72. Höök, M. Timber Volume Element Prefabrication-Production and Market Aspects. Ph.D. Thesis, Luleå University of Technology, Luleå, Sweden, 2005.

73. Walford, G. Multistorey timber building in UK and Sweden. NZ Timber Des. J. 2006, 2, 6-13.

74. Pan, W.; Gibb, A.G.F.; Dainty, A.R.J. Perspectives of house-builders on the use of offsite production in housebuilding. Constr. Manag. Econ. 2007, 25, 183-194. [CrossRef]

75. Cox, A.G.; Piroozfar, P. Prefabrication as a source for co-creation: An investigation into potentials for large-scale prefabrication in the UK. In Proceedings of the 6th Nordic Conference on Construction Economics and Organisation, Copenhagen, Denmark, 13-15 April 2011.

76. Van De Kuilen, J.W.G.; Ceccotti, A.; Xia, Z.; He, M. Very Tall Wooden Buildings with Cross Laminated Timber. Procedia Eng. 2011, 14, 1621-1628. [CrossRef]

77. Pan, W.; Goodier, C. House-Building Business Models and off-Site Construction Take-up. J. Archit. Eng. 2012, 18, 84-93. [CrossRef]

78. Manninen, H. Long-Term Outlook for Engineered Wood Products in Europe; European Forest Institute: Joensuu, Finland, 2014.

79. Waugh, A. From the first to the forefront: Waugh Thistleton's journey from the world's first timber tower to the disruption of construction. In Proceedings of the Woodrise 2017, Bordeau, France, 12-15 September 2017.

80. Asad, S.; Fuller, P.; Pan, W.; Dainty, A.R.J. Learning to innovate in construction: A case study. In Proceedings of the 21st Annual ARCOM Conference, SOAS, London, UK, 7-9 September 2005. 